\title{
Effects of calcium ammonium nitrate fed to dairy cows on nutrient intake and digestibility, milk quality, microbial protein synthesis, and ruminal fermentation parameters
}

\author{
K. V. Almeida, ${ }^{1,2}$ G. T. Santos, ${ }^{1}$ J. L. P. Daniel, ${ }^{1}$ J. A. C. Osorio, ${ }^{1}$ K. L. G. Yamada, ${ }^{1}$ M. R. Sippert, ${ }^{1}$ J. F. Cabral, ${ }^{1}$ \\ F. E. Marchi, ${ }^{1}$ R. C. Araujo, ${ }^{3}$ and D. Vyas ${ }^{4 *}$ \\ ${ }^{1}$ Department of Animal Sciences, State University of Maringa, Maringa, Brazil 87020-900 \\ ${ }^{2}$ Department of Agriculture, Nutrition, and Food Systems, University of New Hampshire, Durham 03824 \\ ${ }^{3}$ GRASP Ind. \& Com. Ltda., Curitiba, Brazil 81260-000 \\ ${ }^{4}$ Department of Animal Sciences, University of Florida, Gainesville 32611
}

\begin{abstract}
We evaluated the effects of supplemental calcium ammonium nitrate (CAN) fed to dairy cows on dry matter (DM) intake, nutrient digestibility, milk quality, microbial protein synthesis, and ruminal fermentation. Six multiparous Holstein cows at $106 \pm 14.8 \mathrm{~d}$ in milk, with $551 \pm 21.8 \mathrm{~kg}$ of body weight were used in a replicated $3 \times 3$ Latin square design. Experimental period lasted $21 \mathrm{~d}$, with $14 \mathrm{~d}$ for an adaptation phase and $7 \mathrm{~d}$ for sampling and data collection. Cows were randomly assigned to receive the following treatments: URE, 12 $\mathrm{g}$ of urea $/ \mathrm{kg}$ of DM as a control group; CAN15, 15 $\mathrm{g}$ of $\mathrm{CAN} / \mathrm{kg}$ of DM; and CAN30, $30 \mathrm{~g}$ of CAN $/ \mathrm{kg}$ of DM. Supplemental CAN reduced DM intake (URE 19.0 vs. CAN15 18.9 vs. CAN30 $16.5 \mathrm{~kg} / \mathrm{d}$ ). No treatment effects were observed for apparent digestibility of $\mathrm{DM}$, organic matter, crude protein, ether extract, and neutral detergent fiber; however, CAN supplementation linearly increased nonfiber carbohydrate digestibility. Milk yield was not affected by treatments (average $=23.1 \mathrm{~kg} / \mathrm{d})$, whereas energy-corrected milk (ECM) and $3.5 \%$ fat-corrected milk (FCM) decreased as the levels of CAN increased. Nitrate residue in milk increased linearly (URE 0.30 vs. CAN15 0.33 vs. CAN30 $0.38 \mathrm{mg} / \mathrm{L}$ ); however, treatments did not affect nitrite concentration (average: $0.042 \mathrm{mg} / \mathrm{L})$. Milk fat concentration was decreased (URE 3.39 vs. CAN15 3.35 vs. CAN30 2.94\%), and the proportion of saturated fatty acids was suppressed by CAN supplementation. No treatment effects were observed on the reducing power and thiobarbituric acid reactive substances of milk, whereas conjugated dienes increased linearly (URE
\end{abstract}

Received August 6, 2021.

Accepted November 20, 2021.

*Corresponding author: diwakarvyas@ufl.edu
47.6 vs. CAN15 52.7 vs. CAN30 $63.4 \mathrm{mmol} / \mathrm{g}$ of fat) with CAN supplementation. Treatments had no effect on microbial protein synthesis; however, molar proportion of ruminal acetate and acetate-to-propionate ratio increased with CAN supplementation. Based on the results observed, supplementing CAN at $30 \mathrm{~g} / \mathrm{kg}$ of DM should not be recommended as an optimal dose because it lowered DM intake along with ECM and 3.5\% FCM, although no major changes were observed on milk quality and ruminal fermentation.

Key words: antioxidant capacity, nonprotein nitrogen, methemoglobin, milk fatty acid

\section{INTRODUCTION}

Nitrate $\left(\mathrm{NO}_{3}^{-}\right)$compounds have been explored as feed additives to decrease methane $\left(\mathrm{CH}_{4}\right)$ production and as dietary NPN sources in ruminants. Recently, Feng et al. (2020), using a meta-analytical approach, reported the efficacy of $\mathrm{NO}_{3}{ }^{-}$supplementation (mean $=16.7 \mathrm{~g} / \mathrm{kg}$ of DM) at reducing $\mathrm{CH}_{4}$ yield $(\mathrm{g} / \mathrm{DMI})$ in both dairy cows $(15.5 \pm 1.15 \%)$ and beef cattle $(8.95 \pm$ $1.76 \%)$. Methane mitigation with $\mathrm{NO}_{3}{ }^{-}$occurs because of its role as an alternative metabolic hydrogen $([\mathrm{H}])$ sink in the rumen, because the reduction from $\mathrm{NO}_{3}{ }^{-}$to $\mathrm{NH}_{3}$ is more thermodynamically favorable than the use of $\mathrm{CO}_{2}$ to synthesize $\mathrm{CH}_{4}$. In addition, nitrite $\left(\mathrm{NO}_{2}{ }^{-}\right)$, an intermediate formed during reduction from $\mathrm{NO}_{3}{ }^{-}$to $\mathrm{NH}_{3}$, is toxic to rumen methanogens (Latham et al., 2016; Popova et al., 2019). Although the efficacy of $\mathrm{NO}_{3}{ }^{-}$at reducing the metabolic activity of methanogens (Patra and Yu, 2013; Popova et al., 2019) is consistent, effects of dietary $\mathrm{NO}_{3}{ }^{-}$on ruminal fermentation parameters remain inconsistent. According to Olijhoek et al. (2016) and Wang et al. (2018), feeding $\mathrm{NO}_{3}{ }^{-}$to dairy cows at 21 and $14.6 \mathrm{~g} / \mathrm{kg}$ of DM, respectively, did not affect total VFA concentration and molar proportion of acetate. However, other studies have reported 
greater acetate proportion and attributed it to the stimulation of a thermodynamically favorable pathway for $[\mathrm{H}]$ disposal during the conversion of $\mathrm{NO}_{3}{ }^{-}$to $\mathrm{NH}_{3}$ (Ungerfeld and Kohn, 2006; Nolan et al., 2010; Latham et al., 2016).

In addition to the role of $\mathrm{NO}_{3}{ }^{-}$as an alternative electron acceptor, $\mathrm{NO}_{3}{ }^{-}$supplementation provides NPN and may favor microbial protein synthesis in dairy cows because of its capacity to provide $\mathrm{NH}_{3}$ to ruminal microbes (Wang et al., 2018). Although it is believed that for diets sufficient in RDP, additional $\mathrm{NH}_{3}$ may not increase microbial protein synthesis (Olijhoek et al., 2016), the absence of effects may also be due to lack of synergy between the rate of fermentable carbohydrate degradation and available ruminal N (Sinclair et al., 1993). Because $\mathrm{NH}_{3}$ synthesis from $\mathrm{NO}_{3}{ }^{-}$is slower compared with urea, we speculated better synergy and more efficient $\mathrm{NH}_{3}$ incorporation for synthesis of microbial protein with $\mathrm{NO}_{3}{ }^{-}$supplementation (Nolan et al., 2010; Li et al., 2012).

Gradual adaptation to dietary $\mathrm{NO}_{3}{ }^{-}$is essential to avoid toxicity to rumen microorganisms and prevent greater levels of blood methemoglobin (MetHb) that can lower the $\mathrm{O}_{2}$ carrying capacity of hemoglobin (Leng, 2008). In addition, gradual inclusion of dietary $\mathrm{NO}_{3}{ }^{-}$allows ruminal microbes to adapt and increase their capability to reduce $\mathrm{NO}_{2}{ }^{-}$(Alaboudi and Jones, 1985), thereby lowering the chances of accumulation of $\mathrm{NO}_{3}{ }^{-}$and $\mathrm{NO}_{2}{ }^{-}$residues under ruminal conditions and subsequently in animal products. However, incomplete ruminal metabolism of dietary $\mathrm{NO}_{3}{ }^{-}$to $\mathrm{NH}_{3}$ may result in ruminal accumulation of $\mathrm{NO}_{3}^{-}$and $\mathrm{NO}_{2}{ }^{-}$, which can be absorbed in blood and recovered in urine and milk (Olijhoek et al., 2016). Dietary $\mathrm{NO}_{3}{ }^{-}$supplemented at $21 \mathrm{~g} / \mathrm{kg}$ of DM in lactating dairy cow diets resulted in negligible concentrations of $\mathrm{NO}_{3}{ }^{-}$in milk and was therefore considered safe for human consumption (Olijhoek et al., 2016; Beauchemin et al., 2020). Nevertheless, we are lacking studies investigating transfer of dietary $\mathrm{NO}_{3}{ }^{-}$and its intermediates $\mathrm{NO}_{2}{ }^{-}$in milk when $\mathrm{NO}_{3}{ }^{-}$supplementation exceeds $21 \mathrm{~g} / \mathrm{kg}$ of DM, and, considering WHO (2011) guidelines of $\mathrm{NO}_{3}{ }^{-}$concentration below $50 \mathrm{mg} / \mathrm{L}$ in the drinking water supply, additional studies are required to validate low transfer of dietary $\mathrm{NO}_{3}{ }^{-}$, regardless of the dose supplemented.

As mentioned earlier, ruminal metabolism of $\mathrm{NO}_{3}{ }^{-}$ results in the formation of intermediates such as $\mathrm{NO}_{2}{ }^{-}$. Nitrates and $\mathrm{NO}_{2}{ }^{-}$absorbed in blood and tissues are physiologically recycled to form nitric oxide (NO) and other bioactive nitrogen oxides (Lundberg et al., 2008). The rapid oxidation of $\mathrm{NO}$ in milk to nitro and nitroso compounds might alter its antioxidant capacity; however, its mechanistic details are not well established
(Titov et al., 2010). We are lacking data to establish whether supplementing $\mathrm{NO}_{3}{ }^{-}$to dairy cows would alter milk antioxidant properties. This is much-needed work, considering the importance of food safety in human health.

We hypothesized that gradual inclusion of calcium ammonium nitrate (CAN) in diets of lactating dairy cows would improve microbial protein synthesis, influence ruminal fermentation, and subsequently affect production, without increasing MetHb levels and inducing toxicity, regardless of the dose used. In addition, we hypothesized that regardless of the dose used, minimal $\mathrm{NO}_{3}{ }^{-}$and $\mathrm{NO}_{2}{ }^{-}$residues would be observed in milk and subsequently no effects will be observed on antioxidant properties of milk. The objectives of this study were to determine the effects of dietary supplementation of different levels of CAN on milk composition, milk antioxidant capacity and fatty acid profiles, nutrient digestibility, ruminal fermentation, and microbial protein synthesis.

\section{MATERIALS AND METHODS}

All procedures involving animals in the experiment were approved by the State University of Maringa (Maringa, Brazil) Animal Care Ethics Committee under protocol number 9512221018. The experiment and laboratorial analyses were conducted at the dairy unit and ruminant nutrition laboratory of the State University of Maringa.

\section{Cows, Experimental Design, and Diets}

Six multiparous Holstein dairy cows $(106.3 \pm 14.8$ DIM; $550.7 \pm 21.8 \mathrm{~kg}$ of BW; mean $\pm \mathrm{SD}$ ), adapted to experimental facilities, were used in a replicated 3 $\times 3$ Latin square design balanced for carryover effects. Each experimental period was $21 \mathrm{~d}$ each, with $14 \mathrm{~d}$ for adaptation to the experimental diets and $7 \mathrm{~d}$ for sampling and data collection. Animals were housed in tiestalls and fed individually for measuring DM intake. Experimental diets were formulated to meet the NRC (2001) requirements for a Holstein cow at mid-lactation with $600 \mathrm{~kg}$ of BW, 110 DIM, and producing $25 \mathrm{~kg}$ of milk per day, with $3.5 \%$ of milk fat, and $3 \%$ of milk protein (Table 1).

Feed ingredients (corn silage, ground corn, and soybean meal) were analyzed for chemical composition before the diet formulation. The source of $\mathrm{NO}_{3}{ }^{-}$was the double salt of CAN decahydrate $\left[5 \mathrm{Ca}\left(\mathrm{NO}_{3}\right)_{2} \cdot \mathrm{NH}_{4} \mathrm{NO}_{3} \cdot 10 \mathrm{H}_{2} \mathrm{O}\right]$, with $85.0 \% \mathrm{DM}, 16.5 \% \mathrm{~N}, 19.6 \% \mathrm{Ca}$, and $76.5 \% \mathrm{NO}_{3}{ }^{-}$ on a DM basis (Yara International). To ensure that all treatments had the same amount of $\mathrm{N}$ and $\mathrm{Ca}$, urea 
Table 1. Ingredient and nutritional composition of the experimental diets containing urea or nitrate as nonprotein nitrogen source

\begin{tabular}{|c|c|c|c|}
\hline \multirow[b]{2}{*}{ Item } & \multicolumn{3}{|c|}{ Treatment $^{1}$} \\
\hline & URE & CAN15 & CAN30 \\
\hline \multicolumn{4}{|l|}{ Ingredient proportion, $\mathrm{g} / \mathrm{kg}$ of DM } \\
\hline Corn silage & 530 & 530 & 530 \\
\hline Ground corn & 305 & 304 & 304 \\
\hline Soybean meal & 121 & 121 & 121 \\
\hline Urea $^{2}$ & 11.9 & 5.94 & 0.00 \\
\hline Calcium ammonium nitrate $^{3}$ & 0.00 & 15.0 & 30.0 \\
\hline Limestone $^{4}$ & 17.3 & 8.65 & 0.00 \\
\hline Mineral and vitamin supplement ${ }^{5}$ & 15.0 & 15.0 & 15.0 \\
\hline \multicolumn{4}{|l|}{ Nutritional composition, g/kg of $\mathrm{DM}^{6}$} \\
\hline DM, as-fed basis & 469 & 468 & 468 \\
\hline $\mathrm{OM}$ & 932 & 928 & 924 \\
\hline $\mathrm{CP}$ & 164 & 164 & 164 \\
\hline $\mathrm{RDP}$ & 113 & 113 & 113 \\
\hline Ether extract & 29.8 & 29.8 & 29.8 \\
\hline NDF & 342 & 342 & 342 \\
\hline Forage NDF & 289 & 289 & 289 \\
\hline Nonfibrous carbohydrate & 421 & 420 & 420 \\
\hline Nitrate & 0.00 & 11.5 & 22.9 \\
\hline $\mathrm{Ca}$ & 9.71 & 9.71 & 9.71 \\
\hline $\mathrm{P}$ & 3.67 & 3.66 & 3.66 \\
\hline $\mathrm{Ca}: \mathrm{P}$ & 2.65 & 2.65 & 2.65 \\
\hline
\end{tabular}

${ }^{1} \mathrm{URE}=$ control, without nitrate, containing $12 \mathrm{~g}$ of urea $/ \mathrm{kg}$ of DM; CAN15 = $15 \mathrm{~g}$ of calcium ammonium nitrate $(\mathrm{CAN}) / \mathrm{kg}$ of DM; CAN30 $=30 \mathrm{~g}$ of CAN $/ \mathrm{kg}$ of DM.

${ }^{2}$ Prote-N, $99.5 \%$ DM and $41.7 \% \mathrm{~N}$ on a DM basis; GRASP Ind. \& Com. Ltda.

${ }^{3}$ Double salt of CAN decahydrate $\left[5 \mathrm{Ca}\left(\mathrm{NO}_{3}\right)_{2} \cdot \mathrm{NH}_{4} \mathrm{NO}_{3} \cdot 10 \mathrm{H}_{2} \mathrm{O}\right](85.0 \% \mathrm{DM} ; 16.5 \% \mathrm{~N}, 19.6 \% \mathrm{Ca}$, and $76.5 \%$ $\mathrm{NO}_{3}{ }^{-}$on a DM basis; Yara).

${ }^{4} 340 \mathrm{~g} / \mathrm{kg}$ of $\mathrm{Ca}$ and $40 \mathrm{~g} / \mathrm{kg}$ of Mg; Granisul Ind. \& Com. Ltda.

${ }^{5}$ Bovigold; composition per $\mathrm{kg}: 120 \mathrm{~g}$ of Ca, $35 \mathrm{~g}$ of P, $15 \mathrm{~g}$ of S, $38 \mathrm{~g}$ of Mg, $50 \mathrm{~g}$ of $\mathrm{K}, 106 \mathrm{~g}$ of Na, $15 \mathrm{mg}$ of Co, $417 \mathrm{mg}$ of $\mathrm{Cu}, 16.5 \mathrm{mg}$ of Cr, $875 \mathrm{mg}$ of Fe, $17.5 \mathrm{mg}$ of I, 1,165 mg of Mn, $15 \mathrm{mg}$ of Se, 2,300 mg of Zn, 350 $\mathrm{mg}$ of F, 170,000 IU of vitamin A, 60,000 IU of vitamin D, 1,000 IU of vitamin E; DSM Tortuga.

${ }^{6}$ Unless otherwise stated.

(Prote-N, GRASP Ind. \& Com. Ltda.; 99.5\% DM, and $41.7 \% \mathrm{~N}$ ), and limestone (Granisul Ind. \& Com. Ltda.; $340 \mathrm{~g}$ of $\mathrm{Ca}$ and $40 \mathrm{~g}$ of $\mathrm{Mg}$ per $\mathrm{kg}$ of product) were used for diet formulation.

Cows were assigned randomly to receive 3 different diets: URE, $12 \mathrm{~g}$ of urea $/ \mathrm{kg}$ of $\mathrm{DM}$ as a control group (without $\mathrm{NO}_{3}{ }^{-}$); CAN15: $15 \mathrm{~g}$ of CAN/kg of DM (11.5 $\mathrm{g} / \mathrm{kg}$ of $\mathrm{NO}_{3}{ }^{-}$on a DM basis); and CAN30: $30 \mathrm{~g}$ of $\mathrm{CAN} / \mathrm{kg}$ of $\mathrm{DM}\left(23 \mathrm{~g} / \mathrm{kg}\right.$ of $\mathrm{NO}_{3}{ }^{-}$on a DM basis). Animals were pre-adapted to the treatments during the first $4 \mathrm{~d}$ of each experimental period, where CAN was gradually added (increasing $25 \%$ per day) until achieving final concentration for each diet. Experimental diets were offered as a TMR, twice a day at 0630 and 1530 $\mathrm{h}$ in proportions of 70 and $30 \%$ of the total DM intake, respectively. Diets were adjusted daily to keep $5 \%$ of refusals and avoid sorting. Animals were weighed at the end of each period before the morning feeding, and the voluntary DM intake was calculated daily during the week of data collection by the difference between the total DM offered and refused.

\section{Sampling and Proximate Analyses}

Sampling and data collection were performed during the last $7 \mathrm{~d}$ of each experimental period. Fecal grab samples $(\sim 100 \mathrm{~g})$ were collected from d 15 to 21 at different times throughout the week (d 15 at $0600, \mathrm{~d}$ 16 at $0800, d 17$ at 1000 , d 18 at 1200 ,d 19 at 1400 , d 20 at 1600 , and $d 21$ at $1800 \mathrm{~h}$ ) and frozen at $-20^{\circ} \mathrm{C}$. Grain mix, corn silage, and refusals were collected daily from d 15 to 20 and frozen at $-20^{\circ} \mathrm{C}$ for analyses. Total mixed ration, refusals, and fecal samples were dried at $60^{\circ} \mathrm{C}$ for $48 \mathrm{~h}$ in a forced-air oven (Heratherm OMS180, Thermo Fisher Scientific) to determine DM content and then ground to pass through $4-\mathrm{mm}$ and $1-\mathrm{mm}$ sieves in a Wiley mill (Thomas Scientific) for chemical analyses.

Feed ingredients were pooled to obtain one sample per period, and fecal and refusals samples were proportionally pooled based on DM to achieve one sample per animal per period. All samples were analyzed according to AOAC (AOAC International, 2012) for total DM content (method 934.01), CP (method 990.03), NDF 
(method 2002.04), ash (method 942.05), and ether extract (method 920.39). Organic matter was calculated by the difference between DM and ash. Nonfibrous carbohydrates were calculated based on Van Soest et al. (1991).

Indigestible NDF (iNDF) was used as an internal marker to estimate total fecal output and subsequently nutrient digestibility (Cochran et al., 1986). Briefly, samples of feed, refusals, and feces were weighed $(0.50$ $\mathrm{g}$ per bag) into Ankom F57 bags (25- $\mu$ m porosity, Ankom Technology) and incubated for $288 \mathrm{~h}$ in 2 rumencannulated dairy cows. Cows were fed a diet composed of $60 \%$ corn silage and $40 \%$ grain mix (DM basis). After removal from the rumen, bags were rinsed in tap water until clear and analyzed for NDF in an Ankom 200 Fiber Analyzer for determination of iNDF. Fecal output was calculated as: iNDF intake $(\mathrm{kg} / \mathrm{d}) / \mathrm{iNDF} \%$ feces, where iNDF intake $(\mathrm{kg} / \mathrm{d})=[\mathrm{iNDF} \% \mathrm{TMR} \times$ TMR offered $(\mathrm{kg} / \mathrm{d})]-[\mathrm{iNDF} \%$ orts $\times$ orts $(\mathrm{kg} / \mathrm{d})]$. Total-tract apparent digestibility (\%) was calculated for all nutrients analyzed as: $100-\{[$ nutrient $\%$ feces $\times$ fecal output $(\mathrm{kg} / \mathrm{d})] /[$ nutrient intake $(\mathrm{kg} / \mathrm{d})]\}$, where nutrient intake $(\mathrm{kg} / \mathrm{d})=[$ nutrient\% TMR $\times$ TMR offered $(\mathrm{kg} / \mathrm{d})]-[$ nutrient\% orts $\times$ orts $(\mathrm{kg} / \mathrm{d})]$.

\section{Milk Collection and Laboratory Assays}

Milking was performed twice daily at 0600 and 1500 $\mathrm{h}$, and milk production was recorded during the last 7 d of each experimental period. Both a.m. and p.m. milk samples were collected on d 15 and d 16 and pooled for each day proportional to the total production for each milking (morning and afternoon). A 50-mL aliquot was collected and preserved using 2-bromo2-nitropropane-1,3-diol to analyze fat, protein, and lactose contents by infrared spectrophotometry (Bentley 2000, Bentley Instrument Inc.), and MUN by Berthelot methodology (Chemspec 150, Bentley Instrument Inc.). The FCM was obtained by correcting milk yield per $3.5 \%$ of fat according to Sklan et al. (1992), and ECM was calculated using the equations proposed by Sjaunja et al. (1990). Another 5 aliquots of $50 \mathrm{~mL}$, including backup samples, were collected and frozen at $-20^{\circ} \mathrm{C}$ for analyses of $\mathrm{NO}_{3}{ }^{-}$and $\mathrm{NO}_{2}{ }^{-}$residues, fatty acid (FA) profile, and antioxidant capacity in milk.

Milk reducing power was analyzed based on the method from Zhu et al. (2002). Absorbance was measured at $700 \mathrm{~nm}$ by a UV-vis spectrophotometer (Spectrum SP2000, Castelnuovo), and results were expressed as gallic acid equivalent per kilogram of milk. Conjugated dienes (CD) were measured at $232 \mathrm{~nm}$ by a UV-vis spectrophotometer (Spectrum SP2000, Castelnuovo), calculated, and expressed as millimoles per kilogram of fat (Kiokias et al., 2006). Thiobarbituric acid reac- tive substances in milk were analyzed as described by Vyncke (1970) at $532 \mathrm{~nm}$ by a UV-vis spectrophotometer (Spectrum SP2000, Castelnuovo), and results were expressed as millimoles of malonaldehyde per kilogram of fat.

Concentration of $\mathrm{NO}_{3}{ }^{-}$was obtained by alkaline catalytic oxidation, which converts nitrogenous compounds into $\mathrm{NO}_{3}^{-}$. Subsequently, through cadmium metal, $\mathrm{NO}_{3}{ }^{-}$was reduced to $\mathrm{NO}_{2}^{-}$and determined by diazotization with sulfanilamide and N-naphthyl (1-naphthyl-ethylenediaminodihydrochloride) as described by Cortas and Wakid (1990).

Milk FA were analyzed via fat extraction by centrifugation, as proposed by Murphy et al. (1995) and esterification according to ISO 5509 method (ISO, 1978) using $\mathrm{KOH}$ and methanol. $N$-Heptane and the methyl esters were quantified in a gas chromatograph (Trace GC 52 Ultra, Thermo Scientific), equipped with a flame ionization detector at $240^{\circ} \mathrm{C}$ and a fused silica capillary column (100 $\mathrm{m}$ in length, 0.25- $\mathrm{mm}$ internal diameter, and $0.20 \mu \mathrm{m}$, Restek 2560). Gas flow rate was $45 \mathrm{~mL} / \mathrm{min}$ of $\mathrm{H}_{2}$ (carrier gas), $45 \mathrm{~mL} / \mathrm{min}$ for $\mathrm{N}_{2}$ (auxiliary gas), and 45 to $400 \mathrm{~mL} / \mathrm{min}$ of synthetic air (flame gas). Column temperature was initially set at $50^{\circ} \mathrm{C}(10 \mathrm{~min})$ and raised gradually up to $200^{\circ} \mathrm{C}(15$ $\mathrm{min}$ ), and finally raised to reach $240^{\circ} \mathrm{C}(8 \mathrm{~min})$ as final temperature. Fatty acids were quantified by comparing retention time of FAME from standards (Sigma Aldrich) and milk samples.

\section{Urine, Blood, and Ruminal Fluid Analyses}

Urine samples were collected on d 17 and d 18 within $4 \mathrm{~h}$ after morning feeding, filtered through 2 layers of cheesecloth, and placed into $50-\mathrm{mL}$ plastic bottles. An aliquot of $10 \mathrm{~mL}$ of urine was acidified with $40 \mathrm{~mL}$ of sulfuric acid $(0.036 N)$ for further analyses. Creatinine was used as a marker to estimate daily urinary volume, assuming a factor for urinary creatinine excretion of $29 \mathrm{mg}$ per kilogram of BW per day (Valadares et al., 1999). Uric acid was measured using a colorimetric assay kit (Gold Analisa), and allantoin was estimated using a method based on Chen and Gomes (1992), adapted to a 96 -well plate reader. Total purine derivatives (PD) were calculated as the sum of uric acid and allantoin excreted in urine. Endogenous PD excretion was calculated from $\mathrm{BW}$ as $0.385 \mathrm{mmol} / \mathrm{BW}^{0.75}$. Daily absorption of microbial purines was calculated as total PD excretion - endogenous PD. Microbial N flow $(\mathrm{g} / \mathrm{d})$ was estimated using daily absorption of microbial purines as (microbial purine absorption $\times 70) /(0.116 \times$ $0.83 \times 1,000)$, according to Chen and Gomes (1992).

Blood was sampled via jugular vein on d 20 of each experimental period before $(0 \mathrm{~h})$ and $4 \mathrm{~h}$ after the 
morning feeding and transported to a commercial laboratory within $1 \mathrm{~h}$ for MetHb analysis. Other samples were collected into serum separator evacuated tubes, centrifuged at $3,200 \times g$ for $15 \mathrm{~min}$ at $4^{\circ} \mathrm{C}$ and stored at $-20^{\circ} \mathrm{C}$ for subsequent analyses. Plasma urea nitrogen (PUN) was analyzed colorimetrically by commercial kits (Gold Analisa) using a spectrophotometer (Bioplus 2000).

Ruminal fluid was collected on d 21 of each period using an esophageal tube attached to a vacuum pump 2 and $8 \mathrm{~h}$ after the morning feeding. An aliquot of $50 \mathrm{~mL}$ was collected, and the $\mathrm{pH}$ was immediately measured by a $\mathrm{pH}$ meter (Tecnal). Another aliquot of $50 \mathrm{~mL}$ was filtered through 4 layers of cheesecloth, acidified with $1 \mathrm{~mL}$ of sulfuric acid $(1: 1)$, and stored at $-20^{\circ} \mathrm{C}$. The concentration of VFA was determined in a gas chromatograph (Shimadzu GC-2010 Plus), equipped with an AOC-20i automatic injector, Stabilwax-DA capillary column (30 m, 0.25-mm ID, $0.25 \mu \mathrm{m}$, Restek), and a flame ionization detector after acidifying with $1 \mathrm{M}$ phosphoric acid and fortifying with a WSFA-2 standard (Sigma Aldrich). A 1- $\mu \mathrm{L}$ aliquot of each sample was injected with a 40:1 split rate using $\mathrm{He}$ as the carrier gas. Injector and detector temperatures were $250^{\circ} \mathrm{C}$ and $300^{\circ} \mathrm{C}$, respectively. Column temperature ramp started at $40^{\circ} \mathrm{C}$, was raised to $120^{\circ} \mathrm{C}$ at a rate of $40^{\circ} \mathrm{C} / \mathrm{min}$, followed by a gradient of $120^{\circ} \mathrm{C}$ to $180^{\circ} \mathrm{C}$ at a rate of $10^{\circ} \mathrm{C} /$ min and a rate of $120^{\circ} \mathrm{C} / \mathrm{min}$ for $180^{\circ} \mathrm{C}$ to $240^{\circ} \mathrm{C}$, maintaining the temperature at $240^{\circ} \mathrm{C}$ for an additional 3 min. Ammonia- $\mathrm{N}\left(\mathrm{NH}_{3}-\mathrm{N}\right)$ concentration was measured via colorimetric quantification of $\mathrm{N}$ content using the phenol-hypochlorite reaction as described by Broderick and Kang (1980).

\section{Statistical Analyses}

Normality of residuals and homogeneity of variance were examined for each variable analyzed, using the Shapiro-Wilk test. Responses that violated the assump- tion of normality were subjected to power transformation using the TRANSREG procedure of SAS (version 9.4, SAS Institute Inc.) as described by Box and Cox (1964). The LSM and SEM were back transformed for presentation of results (Jorgensen and Pedersen, 1998).

Data were analyzed using the MIXED procedure of SAS, using treatment (URE, CAN15, and CAN30) as a fixed effect, and cow within square and period as random effects. Responses with repeated measures were analyzed using the REPEATED statement with statistical models that included the fixed effects of treatment, time, and their interactions, and random effects of cow within Latin square and period. The covariance structure was modeled based on the spatial exponential covariance pattern by using the option TYPE.

Orthogonal polynomial contrasts were used to determine linear and quadratic effects of treatments on the responses analyzed. Treatment significances and trends were declared at $P \leq 0.05$ and $0.05<P \leq 0.10$, respectively. Data were assessed for carryover effects between periods using the ORTHOREG procedure of SAS.

\section{RESULTS}

This study was designed as replicated Latin squares balanced for carryover effects; however, considering the short adaptation period, we analyzed data for carryover effects, and no significant differences (Supplemental Tables S1 and S2, https://doi.org/10.6084/m9.figshare .17159195.v2, https://doi.org/10.6084/m9.figshare .17159225.v2; Almeida, 2021a,b) were observed, except tendencies for allantoin $(P=0.06$; Table S1) and microbial protein synthesis $(P=0.07$; Table $\mathrm{S} 1)$.

\section{DMI and Nutrient Digestibility}

Feeding CAN to dairy cows linearly decreased DMI $(P<0.01$; Table 2$)$. Apparent digestibility of DM, OM, $\mathrm{CP}$, ether extract, and NDF were not affected by treat-

Table 2. Effects of calcium ammonium nitrate (CAN) supplementation on DMI and nutrient digestibility in lactating Holstein dairy cows

\begin{tabular}{|c|c|c|c|c|c|c|}
\hline \multirow[b]{2}{*}{ Item } & \multicolumn{3}{|c|}{ Treatment $^{1}$} & \multirow[b]{2}{*}{ SEM } & \multicolumn{2}{|c|}{$P$-value ${ }^{2}$} \\
\hline & URE & CAN15 & CAN30 & & Linear & Quadratic \\
\hline DMI, kg/d & 19.1 & 18.9 & 16.5 & 0.68 & $<0.01$ & 0.09 \\
\hline \multicolumn{7}{|l|}{ Apparent digestibility, $\mathrm{g} / \mathrm{kg}$ of $\mathrm{DM}$} \\
\hline $\mathrm{DM}$ & 633 & 627 & 639 & 10.1 & 0.55 & 0.34 \\
\hline $\mathrm{OM}$ & 649 & 645 & 658 & 10.1 & 0.44 & 0.37 \\
\hline $\mathrm{CP}$ & 594 & 607 & 588 & 20.3 & 0.77 & 0.35 \\
\hline Ether extract & 661 & 671 & 670 & 11.0 & 0.27 & 0.45 \\
\hline NDF & 474 & 473 & 456 & 21.9 & 0.45 & 0.71 \\
\hline $\mathrm{NFC}$ & 819 & 825 & 869 & 17.0 & 0.01 & 0.22 \\
\hline
\end{tabular}

${ }^{1} \mathrm{URE}=$ control group (without nitrate); CAN15 = $15 \mathrm{~g}$ of CAN per $\mathrm{kg}$ of DM; CAN30 = $30 \mathrm{~g}$ of CAN per kg of DM.

${ }^{2}$ Linear and quadratic effects of CAN. 
Table 3. Effects of calcium ammonium nitrate (CAN) supplementation on milk production, content, yield, and antioxidant capacity in lactating Holstein dairy cows

\begin{tabular}{|c|c|c|c|c|c|c|}
\hline \multirow[b]{2}{*}{ Item } & \multicolumn{3}{|c|}{ Treatment $^{1}$} & \multirow[b]{2}{*}{ SEM } & \multicolumn{2}{|c|}{$P$-value ${ }^{2}$} \\
\hline & URE & CAN15 & CAN30 & & Linear & Quadratic \\
\hline \multicolumn{7}{|l|}{ Production, kg/d } \\
\hline Milk & 23.3 & 23.2 & 23.0 & 1.31 & 0.55 & 0.93 \\
\hline $3.5 \% \mathrm{FCM}^{3}$ & 22.8 & 22.5 & 20.7 & 1.03 & 0.05 & 0.38 \\
\hline $\mathrm{ECM}^{4}$ & 22.6 & 22.4 & 20.7 & 0.99 & 0.05 & 0.32 \\
\hline ECM/DMI & 1.19 & 1.19 & 1.26 & 0.05 & 0.03 & 0.27 \\
\hline \multicolumn{7}{|l|}{ Content, \% } \\
\hline Fat & 3.39 & 3.35 & 2.94 & 0.23 & 0.03 & 0.25 \\
\hline True protein & 3.03 & 3.10 & 2.91 & 0.07 & 0.09 & 0.05 \\
\hline Lactose & 4.64 & 4.61 & 4.58 & 0.07 & 0.35 & 1.00 \\
\hline \multicolumn{7}{|l|}{ Yield, $\mathrm{kg} / \mathrm{d}$} \\
\hline Fat & 0.78 & 0.77 & 0.66 & 0.04 & 0.03 & 0.30 \\
\hline True protein & 0.71 & 0.72 & 0.67 & 0.04 & 0.19 & 0.29 \\
\hline Lactose & 1.08 & 1.07 & 1.05 & 0.06 & 0.35 & 0.90 \\
\hline \multicolumn{7}{|l|}{ Antioxidant capacity } \\
\hline Reducing power ${ }^{5}$ & 12.7 & 13.7 & 12.3 & 1.91 & 0.89 & 0.61 \\
\hline Conjugated dienes ${ }^{6}$ & 47.6 & 52.6 & 63.4 & 6.56 & 0.02 & 0.59 \\
\hline TBARS $^{7}$ & 6.42 & 6.04 & 7.03 & 1.23 & 0.60 & 0.49 \\
\hline MUN, mg/dL & 13.4 & 14.0 & 13.9 & 0.96 & 0.53 & 0.50 \\
\hline \multirow{2}{*}{\multicolumn{7}{|c|}{$\begin{array}{l}{ }^{1} \mathrm{URE}=\text { control group (without nitrate); CAN15 }=15 \mathrm{~g} \text { of CAN per } \mathrm{kg} \text { of DM = CAN30: } 30 \mathrm{~g} \text { of CAN p } \\
\mathrm{kg} \text { of DM. }\end{array}$}} \\
\hline & & & & & & \\
\hline \multicolumn{7}{|c|}{${ }^{2}$ Linear and quadratic effects of CAN. } \\
\hline \multicolumn{7}{|c|}{${ }^{3}$ Sklan et al., 1992.} \\
\hline \multicolumn{7}{|c|}{${ }^{4}$ Sjaunja et al., 1990.} \\
\hline \multicolumn{7}{|c|}{${ }^{5}$ Milligrams of gallic acid equivalents per liter. } \\
\hline${ }^{6}$ Millimoles per kilogr & & & & & & \\
\hline
\end{tabular}

ments; however, NFC digestibility linearly increased with CAN supplementation $(P=0.01$; Table 2$)$.

\section{Yield, Composition, Antioxidant Capacity, and Nitrate and Nitrite Concentrations in Milk}

Supplemental CAN did not affect milk yield (Table 3); however, 3.5\% FCM and ECM were decreased $(P$ $=0.05$; linear effect), whereas feed efficiency (ECM/ DMI) was linearly increased $(P=0.03$; linear effect $)$. Dietary CAN linearly reduced $(P=0.03$; linear effect $)$ fat concentration, whereas true protein concentration was quadratically affected $(P=0.05$; quadratic effect $)$ with greater effects observed with CAN15 compared with URE and CAN30. No effects were observed on milk lactose and MUN concentration (Table 3).

Milk reducing power was not affected by CAN supplementation (Table 3). Similarly, no CAN effect was observed on concentration of thiobarbituric acid reactive substances, whereas the concentration of $\mathrm{CD}$ in milk linearly increased $(P=0.02$; linear effect) as the levels of CAN increased (Table 3).

Nitrate concentration in milk linearly increased with dietary inclusion of CAN $(P=0.02$; linear effect; Figure 1a), but no effects were observed on milk $\mathrm{NO}_{2}{ }^{-}$residues (average: $0.042 \mathrm{mg} / \mathrm{L}$; Figure 1b).

\section{Milk Fatty Acids Profile}

No significant treatment differences were observed on milk FA proportions of 6:0, 8:0, 10:0, and 11:0 (Table $4)$; however, feeding CAN linearly decreased the proportions of 12:0 $(P=0.01$; linear effect $)$ and 13:0 ( $P$ $<0.01$; linear effect). The proportion of 14:0, 14:1, and 15:1 were unaffected, whereas 15:0 linearly decreased $(P<0.01$; linear effect $)$ with CAN supplementation. The proportion of 16:0 was linearly decreased $(P=$ 0.02; linear effect) with CAN supplementation; however, no effects were observed on the proportion of $16: 1$, 17:0, 17:1, and 18:0. Similarly, we observed no effects of CAN supplementation on trans-9 18:1, cis-6 18:2, cis-9 18:1, and 18:3n-6, whereas trans-6 18:2 $(P=0.06)$ and 18:3n-3 $(P=0.09)$ tended to increase linearly with CAN supplementation. Proportions of cis-9,trans-11 CLA and trans-10,cis-12 CLA were not affected by treatment, but 20:0 $(P=0.04$; linear effect $)$ and 21:0 $(P=0.03$; linear effect) were linearly increased, and no effects were observed on 20:1 and 20:2 with CAN supplementation (Table 4).

Total SFA linearly decreased $(P=0.05$; linear effect), whereas MUFA ( $P=0.06$; linear effect; Table $4)$ and PUFA $(P=0.10$; linear effect; Table 4$)$ tended to increase linearly with CAN supplementation. Total 
(a)

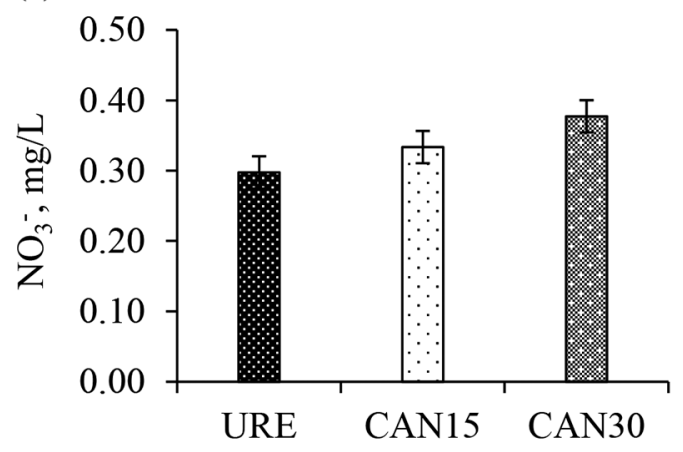

(b)

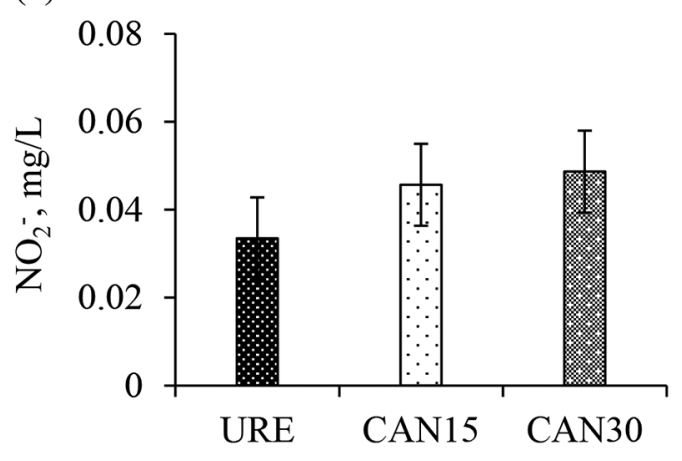

Figure 1. Effects of calcium ammonium nitrate $(\mathrm{CAN})$ supplementation on (a) milk nitrate concentration $\left(\mathrm{NO}_{3}{ }^{-} ; P\right.$-values: linear $=0.02$; quadratic $=0.87 ; \mathrm{SEM}=0.02)$ and $(\mathrm{b})$ milk nitrite concentration $\left(\mathrm{NO}_{2}{ }^{-} ; P\right.$-values: linear $=0.26 ;$ quadratic $\left.=0.69 ; \mathrm{SEM}=0.009\right)$. URE $=$ control group (without nitrate); CAN15 $=15 \mathrm{~g}$ of CAN per $\mathrm{kg}$ of DM; CAN30 $=30 \mathrm{~g}$ of CAN per $\mathrm{kg}$ of DM.

Table 4. Effects of calcium ammonium nitrate (CAN) supplementation on milk fatty acid (FA) profile in lactating Holstein dairy cows

\begin{tabular}{|c|c|c|c|c|c|c|}
\hline \multirow[b]{2}{*}{ Item $^{1}$} & \multicolumn{3}{|c|}{ Treatment $^{2}$} & \multirow[b]{2}{*}{ SEM } & \multicolumn{2}{|c|}{$P$-value ${ }^{3}$} \\
\hline & URE & CAN15 & CAN30 & & Linear & Quadratic \\
\hline \multicolumn{7}{|l|}{ FA proportions } \\
\hline $6: 0$ & 0.40 & 0.41 & 0.47 & 0.05 & 0.36 & 0.69 \\
\hline $8: 0$ & 0.63 & 0.62 & 0.65 & 0.05 & 0.68 & 0.79 \\
\hline 10:0 & 2.66 & 2.60 & 2.52 & 0.20 & 0.44 & 0.92 \\
\hline 11:0 & 0.25 & 0.24 & 0.21 & 0.02 & 0.10 & 0.59 \\
\hline $12: 0$ & 4.60 & 4.32 & 4.02 & 0.32 & 0.01 & 0.98 \\
\hline 13:0 & 0.29 & 0.27 & 0.22 & 0.02 & $<0.01$ & 0.39 \\
\hline $14: 0$ & 15.7 & 15.7 & 15.2 & 0.57 & 0.50 & 0.69 \\
\hline $14: 1$ & 1.45 & 1.43 & 1.49 & 0.06 & 0.64 & 0.55 \\
\hline $15: 0$ & 2.87 & 2.83 & 2.57 & 0.18 & $<0.01$ & 0.16 \\
\hline $15: 1$ & 0.28 & 0.25 & 0.25 & 0.04 & 0.37 & 0.67 \\
\hline $16: 0$ & 37.9 & 36.9 & 35.2 & 1.24 & 0.02 & 0.67 \\
\hline $16: 1$ & 2.00 & 2.00 & 2.08 & 0.13 & 0.52 & 0.69 \\
\hline $17: 0$ & 1.00 & 0.97 & 1.01 & 0.05 & 0.73 & 0.43 \\
\hline $17: 1$ & 0.17 & 0.17 & 0.20 & 0.03 & 0.27 & 0.70 \\
\hline $18: 0$ & 8.49 & 8.51 & 9.16 & 0.58 & 0.35 & 0.60 \\
\hline trans-9 18:1 & 5.39 & 5.39 & 5.89 & 0.53 & 0.40 & 0.62 \\
\hline cis-9 18:1 & 13.6 & 14.6 & 15.8 & 1.22 & 0.14 & 0.91 \\
\hline trans-6 $18: 2$ & 0.59 & 0.72 & 0.77 & 0.08 & 0.06 & 0.60 \\
\hline cis-6 $18: 2$ & 1.00 & 1.13 & 1.19 & 0.09 & 0.13 & 0.77 \\
\hline $18: 3 n-6$ & 0.05 & 0.07 & 0.05 & 0.01 & 0.75 & 0.31 \\
\hline $18: 3 n-3$ & 0.04 & 0.05 & 0.06 & 0.00 & 0.09 & 0.42 \\
\hline cis-9,trans-11 CLA & 0.00 & 0.17 & 0.11 & 0.09 & 0.40 & 0.31 \\
\hline trans-10,cis-12 CLA & 0.01 & 0.01 & 0.01 & 0.01 & 0.96 & 0.93 \\
\hline $20: 0$ & 0.11 & 0.13 & 0.14 & 0.00 & 0.04 & 0.84 \\
\hline $20: 1$ & 0.02 & 0.04 & 0.05 & 0.02 & 0.31 & 0.98 \\
\hline $20: 2$ & 0.06 & 0.05 & 0.09 & 0.01 & 0.53 & 0.31 \\
\hline $21: 0$ & 0.23 & 0.28 & 0.42 & 0.06 & 0.03 & 0.50 \\
\hline \multicolumn{7}{|l|}{ FA groups } \\
\hline SFA & 75.2 & 73.8 & 71.8 & 1.77 & 0.05 & 0.83 \\
\hline MUFA & 23.0 & 23.9 & 25.8 & 1.55 & 0.06 & 0.68 \\
\hline PUFA & 1.71 & 2.18 & 2.21 & 0.22 & 0.10 & 0.38 \\
\hline $\mathrm{n}-3$ & 0.04 & 0.05 & 0.06 & 0.01 & 0.09 & 0.42 \\
\hline n-6 & 1.66 & 2.12 & 2.16 & 0.21 & 0.10 & 0.38 \\
\hline n- $6: n-3$ ratio & 38.0 & 39.3 & 39.1 & 2.95 & 0.65 & 0.72 \\
\hline Total CLA $^{4}$ & 0.02 & 0.20 & 0.13 & 0.10 & 0.46 & 0.37 \\
\hline
\end{tabular}

${ }^{1} \mathrm{G}$ per $100 \mathrm{~g}$ of total FA.

${ }^{2} \mathrm{URE}=$ control group (without nitrate); CAN15 = $15 \mathrm{~g}$ of CAN per $\mathrm{kg}$ of DM; CAN30 = $30 \mathrm{~g}$ of CAN per $\mathrm{kg}$ of DM.

${ }^{3}$ Linear and quadratic effects of CAN.

${ }^{4}$ Total CLA $=$ cis-9,trans-11 CLA + trans-10,cis-12 CLA. 
Table 5. Effects of calcium ammonium nitrate (CAN) supplementation on allantoin, uric acid, and microbial protein synthesis in lactating Holstein dairy cows

\begin{tabular}{|c|c|c|c|c|c|c|}
\hline \multirow[b]{2}{*}{ Item } & \multicolumn{3}{|c|}{ Treatment $^{1}$} & \multirow[b]{2}{*}{ SEM } & \multicolumn{2}{|c|}{$P$-value ${ }^{2}$} \\
\hline & URE & CAN15 & CAN30 & & Linear & Quadratic \\
\hline Uric acid, $\mathrm{mmol} / \mathrm{d}$ & 50.9 & 55.9 & 67.2 & 8.56 & 0.06 & 0.63 \\
\hline Microbial protein synthesis, ${ }^{3} \mathrm{~g} / \mathrm{d}$ & 1,871 & 1,955 & 1,970 & 173 & 0.37 & 0.71 \\
\hline
\end{tabular}

${ }^{1} \mathrm{URE}=$ control group (without nitrate); CAN15 = $15 \mathrm{~g}$ of CAN per $\mathrm{kg}$ of DM; CAN30 = $30 \mathrm{~g}$ of CAN per $\mathrm{kg}$ of DM.

${ }^{2}$ Linear $=$ linear effect of CAN; Quadratic $=$ quadratic effect of CAN .

${ }^{3}$ Chen and Gomes $(1992)=\left\{\left[\right.\right.$ purine derivatives production $\left.\left.-\left(0.385 \times \mathrm{BW}^{0.75}\right)\right] / 0.85\right\} \times 0.727$.

CLA and n-6:n-3 ratio were not affected by treatments, but $\mathrm{n}-3(P=0.09$; linear effect $)$ and $\mathrm{n}-6(P=0.10$; linear effect) FA tended to increase linearly with CAN supplementation (Table 4).

\section{Blood Parameters and Microbial Protein Synthesis}

Levels of PUN were not affected by supplemental CAN (Supplemental Figure S1, https://doi.org/ 10.6084/m9.figshare.17159240.v2; Almeida, 2021c); however, MetHb (\% of hemoglobin) increased linearly with CAN supplementation $(P<0.01$; linear effect $)$ regardless of the sampling time (Supplemental Figure S2, https://doi.org/10.6084/m9.figshare.17159252.v2; Almeida, 2021d). Supplemental CAN did not affect allantoin excretion and microbial protein synthesis but tended to increase uric acid concentration $(P=0.06$; linear effect; Table 5).

\section{Ruminal Fermentation Parameters}

No interactions between time $(2$ and $8 \mathrm{~h}$ after feeding) and treatment were observed on ruminal $\mathrm{pH}, \mathrm{NH}_{3}-$
$\mathrm{N}$ concentration, and VFA profile (data not shown). Total VFA, molar proportion of propionate, and butyrate were not affected by treatments (Table 6). However, the molar proportion of acetate linearly increased $(P$ $<0.01$; linear effect) and acetate-to-propionate ratio tended to increase $(P=0.07$; linear effect) with CAN supplementation. Isovalerate $(P=0.01$; linear effect $)$ and valerate proportions $(P=0.01$; linear effect) were linearly decreased, and isobutyrate tended to decrease with CAN supplementation $(P=0.08$; linear effect; Table 6).

\section{DISCUSSION}

Supplemental $\mathrm{NO}_{3}{ }^{-}$has been established as an effective feed additive for mitigating $\mathrm{CH}_{4}$ emissions in ruminants (Lee and Beauchemin, 2014; Beauchemin et al., 2020; Feng et al., 2020). However, studies aiming to evaluate milk characteristics such as antioxidant capacity and residues of $\mathrm{NO}_{3}^{-}$and $\mathrm{NO}_{2}^{-}$in response to $\mathrm{NO}_{3}{ }^{-}$supplementation are still needed, due to the importance of milk for human consumption. We evaluated milk composition of lactating dairy cows along with

Table 6. Effects of calcium ammonium nitrate (CAN) supplementation on ruminal $\mathrm{pH}, \mathrm{NH}_{3}-\mathrm{N}$ concentration, and VFA profile in lactating Holstein dairy cows

\begin{tabular}{|c|c|c|c|c|c|c|}
\hline \multirow[b]{2}{*}{ Item } & \multicolumn{3}{|c|}{ Treatment $^{1}$} & \multirow[b]{2}{*}{ SEM } & \multicolumn{2}{|c|}{$P$-value ${ }^{2}$} \\
\hline & URE & CAN15 & CAN30 & & Lin & Quad \\
\hline $\mathrm{pH}$ & 6.80 & 6.75 & 6.78 & 0.13 & 0.88 & 0.71 \\
\hline $\mathrm{NH}_{3}-\mathrm{N}, \mathrm{m} M$ & 13.3 & 10.9 & 10.5 & 1.22 & 0.27 & 0.64 \\
\hline Total VFA, mM & 73.0 & 72.5 & 71.7 & 6.17 & 0.85 & 0.97 \\
\hline \multicolumn{7}{|c|}{ Individual VFA, mol/100 mol } \\
\hline Acetate & 59.2 & 60.7 & 63.0 & 1.24 & $<0.01$ & 0.54 \\
\hline Propionate & 23.6 & 23.9 & 21.7 & 1.64 & 0.20 & 0.34 \\
\hline Isobutyrate & 0.83 & 0.75 & 0.77 & 0.05 & 0.08 & 0.10 \\
\hline Butyrate & 12.7 & 11.4 & 11.8 & 0.68 & 0.27 & 0.24 \\
\hline Isovalerate & 1.81 & 1.61 & 1.33 & 0.17 & 0.01 & 0.81 \\
\hline Valerate & 1.77 & 1.71 & 1.44 & 0.16 & 0.01 & 0.33 \\
\hline Acetate:propionate & 2.59 & 2.65 & 2.95 & 0.20 & 0.07 & 0.42 \\
\hline
\end{tabular}


antioxidant properties of milk and rumen fermentation parameters in response to CAN supplementation. The 14-d adaptation period used in this study is admittedly short and may not be long enough to allow for adaptation of microbes; hence, data should be interpreted cautiously. Long-term studies are needed, to confirm the findings observed in the present study.

\section{Feed Intake and Nutrient Digestibility}

Nitrate supplementation reduced feed intake by $13 \%$ in the present study. In agreement with our findings, Lund et al. (2014) reported lower DMI with $20 \mathrm{~g} / \mathrm{kg}$ of DM of CAN supplementation in dairy cows. Similarly, supplemental CAN (up to $23 \mathrm{~g} / \mathrm{kg} \mathrm{NO}_{3}{ }^{-}$on a DM basis) reduced intake of both pasture and concentrate in grazing cows, subsequently lowering milk production (van Wyngaard et al., 2018). Recently, Meller et al. (2019) also observed lower DMI with CAN fed to Jersey cows $\left(20 \mathrm{~g} / \mathrm{kg} \mathrm{NO}_{3}{ }^{-}\right.$on DM basis). The effects of CAN supplementation on lowering feed intake may be attributable to lower palatability of the diets due to the bitter taste of $\mathrm{NO}_{3}{ }^{-}$salts (Lee and Beauchemin, 2014). Lower DMI in response to CAN supplementation may have resulted in the lower ECM and FCM observed in the present study. Encapsulating $\mathrm{NO}_{3}{ }^{-}$salts can alleviate negative effects of $\mathrm{NO}_{3}{ }^{-}$supplementation on DMI (Lee et al., 2015b), as its slow release would ensure faster conversion of $\mathrm{NO}_{3}{ }^{-}$to $\mathrm{NH}_{3}$. However, encapsulation may lower the efficacy of $\mathrm{NO}_{3}{ }^{-}$at inhibiting methanogens, thereby reducing the antimethanogenic potential of $\mathrm{NO}_{3}{ }^{-}$supplementation. Nevertheless, previous studies using an encapsulated $\mathrm{NO}_{3}{ }^{-}$source with vegetable oil (GRASP Ind. \& Com. Ltda.; EW Nutrition $\mathrm{GmbH}$ ) did not reduce negative effects on feed intake (Lee et al., 2015a; Rebelo et al., 2019). Future studies are required to evaluate supplementing $\mathrm{NO}_{3}{ }^{-}$ salts combined with other feed additives that could enhance feed palatability; for instance, molasses, which, according to DeVries and Gill (2012), increases feed palatability and minimizes negative effects on DMI and milk yield.

Supplemental CAN had no effect on nutrient digestibility in dairy cows, and the effects may be attributable to gradual adaptation of dairy cows to $\mathrm{NO}_{3}{ }^{-}$diets, possibly alleviating the effects of CAN on rumen microbiota and, subsequently, nutrient digestibility. Zhou et al. (2012) reported, using an in vitro study, that supplementing $\mathrm{NO}_{3}{ }^{-}$at $12 \mu \mathrm{mol} / \mathrm{mL}(\sim 12 \mathrm{~g} / \mathrm{kg}$ of DM) decreased methanogens ( $\sim 97 \%$ less $)$ and also decreased the abundance of cellulolytic bacteria (Fibrobacter succinogenes, Ruminococcus albus, and Ruminococcus flavefaciens). Increased redox potential and $\mathrm{NO}_{2}^{-}$ac- cumulation may negatively affect NDF digestibility (Zhou et al., 2012). Nevertheless, the lack of effects on nutrient digestibility observed in the present study is in agreement with earlier studies evaluating dietary $\mathrm{NO}_{3}{ }^{-}$ in dairy cows (van Zijderveld et al., 2011; Olijhoek et al., 2016; Wang et al., 2018). The lack of $\mathrm{NO}_{3}{ }^{-}$effects on nutrient digestibility might be attributable to the dose used; however, we cannot rule out the confounding effect of lower intake with $\mathrm{NO}_{3}{ }^{-}$and subsequently slower passage rate on nutrient digestibility. The linear improvement in NFC digestibility observed in this study might be attributable to increased starch digestibility, since starch is a major constituent of NFC. However, the effects of CAN supplementation on increased starch digestibility are difficult to explain considering lack of $\mathrm{NO}_{3}{ }^{-}$effects on total VFA and ruminal propionate.

\section{Milk Composition and Milk Antioxidant Capacity}

Both ECM and FCM were lower with $\mathrm{NO}_{3}{ }^{-}$supplementation, and these effects could be attributed to lower DMI and fat content observed in the present study. Similar findings have been observed earlier, as van Wyngaard et al. (2018) reported negative effects of $\mathrm{NO}_{3}{ }^{-}$supplementation on FCM and ECM due to a reduction in fat and protein content, respectively. However, Olijhoek et al. (2016) did not find differences in ECM in response to supplementing CAN at $21 \mathrm{~g} /$ $\mathrm{kg}$ (DM basis), and the results were attributed to lack of differences in DMI, nutrient digestibility, and rumen fermentation parameters.

The effects of $\mathrm{NO}_{3}{ }^{-}$on decreasing milk fat yield may be explained by lower DMI, including NDF fractions. Similarly, milk protein concentration was quadratically affected, with greater values observed for CAN15 and lower values observed with CAN30. van Zijderveld et al. (2011) observed reduction in milk protein concentration with supplementation of $21 \mathrm{~g} / \mathrm{kg} \mathrm{NO}_{3}{ }^{-}$on a DM basis for $89 \mathrm{~d}$ and attributed this to a dilution effect. Milk protein responses might be attributable to the effects of $\mathrm{NO}_{3}{ }^{-}$supplementation on DMI, which may have affected ruminal and post-ruminal $\mathrm{N}$ availability and subsequently milk protein synthesis, although no effects were observed on microbial protein synthesis, which makes it difficult to explain. Similarly, Klop et al. (2016) evaluated $\mathrm{NO}_{3}{ }^{-}$versus docosahexaenoic acid in a factorial arrangement of treatments and observed low protein content and yield when supplementing 21 $\mathrm{g} / \mathrm{kg} \mathrm{DM}$ of $\mathrm{NO}_{3}{ }^{-}$to dairy cows. The effects on milk protein responses were attributed to lower DMI and limited supply of gluconeogenic precursors with $\mathrm{NO}_{3}{ }^{-}$ supplementation (Klop et al., 2016). Milk urea nitrogen was also unaffected by treatment, and similar findings 
were observed earlier with supplemental $\mathrm{NO}_{3}{ }^{-}$(van Zijderveld et al., 2011; Klop et al., 2016; van Wyngaard et al., 2018).

To the best of our knowledge, we are lacking data on the effects of supplemental $\mathrm{NO}_{3}{ }^{-}$on milk antioxidant capacity. In addition to FA, vitamins, and minerals, the antioxidant capacity of milk has potential for improving human health by removing free radicals from the body (Khan et al., 2019). In our study, reducing power and thiobarbituric acid reactive substances were unaffected by treatment; however, CD linearly increased with CAN supplementation. Conjugated dienes are considered an indicator of lipid peroxidation (Guillén and Cabo, 2002). Although we are still lacking a concrete explanation for the increase in $\mathrm{CD}$ in response to $\mathrm{NO}_{3}{ }^{-}$supplementation, we can speculate that lower SFA, along with a tendency to increase MUFA and PUFA as a response to CAN supplementation, may have predisposed milk FA to oxidation, resulting in greater concentration of CD. Previous studies have shown that oxidation of UFA contributes to the formation of hydroperoxide and shifts of double bonds (Hamilton, 1983; Jadhav et al., 1996). Another speculation is that greater concentrations of $\mathrm{NO}_{3}{ }^{-}$and $\mathrm{NO}_{2}{ }^{-}$may form $\mathrm{NO}$ and other bioactive nitrogen oxides after being absorbed in the blood and tissues (Lundberg et al., 2008). The presence of NO in milk can induce nitrosative stress due to its reaction with oxygen, superoxide, or hydroperoxide (Silanikove et al., 2009, 2012). Thus, these reactions likely lowered milk antioxidant capacity and induced lipid peroxidation, resulting in greater production of CD.

\section{Nitrate and Nitrite Residues in Milk}

Nitrate as a feed additive for dairy cows may induce potential toxicity if animals are not well adapted to the treatments. Furthermore, presence of $\mathrm{NO}_{3}{ }^{-}$or $\mathrm{NO}_{2}{ }^{-}$ residues in animal tissues and products such as meat and milk may cause health problems in humans (Bryan and van Grinsven, 2013; Lee et al., 2017a). Based on WHO (2011) guidelines, the maximum $\mathrm{NO}_{3}{ }^{-}$concentration in milk for safe consumption is $50 \mathrm{mg} / \mathrm{L}$. We observed greater levels of milk $\mathrm{NO}_{3}{ }^{-}$(0.30 to $0.38 \mathrm{mg} / \mathrm{L}$ for URE and CAN30, respectively) with CAN supplementation, whereas $\mathrm{NO}_{2}^{-}$residue was similar for all treatments, averaging $43 \mu \mathrm{g} / \mathrm{L}$. Olijhoek et al. (2016) observed much greater $\mathrm{NO}_{3}^{-}$residue $(1.56 \mathrm{mg} / \mathrm{L})$ in milk with CAN supplementation $(21.1 \mathrm{~g} / \mathrm{kg}$ on DM basis); however, $\mathrm{NO}_{2}{ }^{-}$residues were not detected. Overall, studies have shown low $\mathrm{NO}_{3}{ }^{-}$and $\mathrm{NO}_{2}{ }^{-}$residues in milk with $\mathrm{NO}_{3}{ }^{-}$supplementation in dairy cows, suggesting that consuming milk from treated dairy cows would not be a concern for food safety (Guyader et al., 2016a; Meller et al., 2019).

\section{Milk Fatty Acid Profile}

Dietary manipulation can have significant effects on the milk FA profile in dairy cows (Lock and Bauman, 2004). Klop et al. (2016) investigated the effects of $\mathrm{NO}_{3}{ }^{-}$and docosahexaenoic acid on the milk FA profile and observed no effects on SFA and MUFA profiles with $\mathrm{NO}_{3}{ }^{-}$supplementation; however, the PUFA proportion was increased. In the current study, we observed lower SFA and greater proportions of MUFA and PUFA in milk. Nitrates and $\mathrm{NO}_{2}{ }^{-}$are alternative $[\mathrm{H}]$ sinks that divert $\mathrm{H}_{2}$ away from methanogenesis and biohydrogenation, which would explain lower SFA in the present study; however, we are still lacking enough studies validating this hypothesis because of low $\mathrm{H}_{2}$ dissipation at the expense of ruminal biohydrogenation (Yang et al., 2019). Indeed, similar to our results, Sharifi et al. (2021) observed no effects of $\mathrm{NO}_{3}{ }^{-}$supplementation to dairy cows on 18:0 proportion, as indicative of biohydrogenation in the rumen. According to Lourenço et al. (2010), biohydrogenation could be affected indirectly when other ruminal activities are changed (i.e., $\mathrm{CH}_{4}$ inhibition), because FA metabolism is strictly dependent on the microbial species that are involved in multiple metabolic processes along with $\mathrm{H}_{2}$ metabolism. In fact, $\mathrm{NO}_{3}{ }^{-}$intermediates have toxic effects on ruminal microorganisms, including the fibrolytic bacteria and methanogens (Latham et al., 2016). We can speculate that $\mathrm{NO}_{2}^{-}$might have negatively affected ruminal abundance of a predominant biohydrogenating bacteria, Butyrivibrio proteoclasticus, as observed earlier in response to $\mathrm{NaNO}_{2}{ }^{-}(2 \mathrm{~g} / \mathrm{L})$ supplementation in highconcentrate diets under in vitro conditions (Yang et al., 2019). Changes in ruminal bacteria populations may be associated with the effects observed on the milk FA profile in the current study.

Lower SFA may be considered positive for milk quality because of perceived effects of SFA on cardiac health (Lock and Bauman, 2004). Nevertheless, it is well established that milk with greater MUFA and PUFA proportions is more susceptible to lipid oxidation than milk with greater proportions of SFA (Zhao et al., 2013). Therefore, we can speculate that lower SFA and greater MUFA and PUFA may have predisposed milk FA to oxidation, resulting in increased concentration of CD.

\section{Blood Methemoglobin and Plasma Urea Nitrogen}

Nitrate poisoning is still a concern with its inclusion in the diets of dairy cows. However, a prior and gradual adaptation may lower the risk of $\mathrm{NO}_{3}{ }^{-}$toxicity, due to low levels of MetHb. In the present study, MetHb linearly increased with increased dietary $\mathrm{NO}_{3}{ }^{-}$levels, 
and greater levels were observed $4 \mathrm{~h}$ after feeding (3.26\% hemoglobin) for CAN30. However, the levels of MetHb observed were much lower than the 30 to $40 \%$ hemoglobin required to induce methemoglobinemia (Bruning-Fann and Kaneene, 1993). The levels of MetHb observed in this study were lower than previous studies evaluating dietary $\mathrm{NO}_{3}{ }^{-}$in changeover $(4.8 \%$; Olijhoek et al., 2016) and continuous studies (4.7\%; van Zijderveld et al., 2011). Supplementing CAN up to $30 \mathrm{~g} / \mathrm{kg}$ on DM basis with a gradual adaptation might have resulted in lower levels of MetHb, thereby lowering the chance of $\mathrm{NO}_{3}{ }^{-}$toxicity.

Treatment did not affect the concentration of PUN; however, PUN levels increased $4 \mathrm{~h}$ after feeding. We assume, with such an effect, that URE, CAN15, and CAN30 provided similar amounts of $\mathrm{N}$ to be absorbed through the rumen wall. Contrary to our findings, Wang et al. (2018) observed greater levels of $\mathrm{NH}_{3}$ in the plasma of cows receiving urea compared with supplemental $\mathrm{NO}_{3}{ }^{-}(14.6 \mathrm{~g} / \mathrm{kg}$ of $\mathrm{DM})$.

\section{Microbial Protein Synthesis, Ammonia-N, and VFA Proportions}

Besides acting as an $[\mathrm{H}]$ sink, $\mathrm{NO}_{3}{ }^{-}$salts are sources of NPN, essential for the rumen microbiota to synthesize microbial protein. Wang et al. (2018) speculated that sodium nitrate increased $\mathrm{NH}_{3}$ incorporation into microbial protein in the rumen compared with urea in cows fed a low-protein diet. In our study, treatment did not affect microbial protein synthesis, suggesting that CAN seemed to have similar efficacy at providing $\mathrm{NH}_{3}$ for bacteria growth, and such results agree with previous findings (Olijhoek et al., 2016) when $\mathrm{NO}_{3}{ }^{-}$ was supplemented up to $21 \mathrm{~g} / \mathrm{kg}$ of DM in the diet of lactating dairy cows. However, the estimation of microbial protein synthesis by PD must be interpreted with caution because of inaccurate relationship observed between microbial protein synthesis and urinary excretion of PD, as suggested recently (Hristov et al., 2019). Total PD used to evaluate microbial protein synthesis may not accurately reflect changes in microbial protein flow because duodenal digestibility of purines and recovery in urine are influenced by dietary factors as well as by the physiological state of animals (Dewhurst et al., 2000).

Nitrate supplementation had no effects on ruminal $\mathrm{NH}_{3}-\mathrm{N}$ concentration, corroborating previous studies that evaluated supplemental $\mathrm{NO}_{3}{ }^{-}$fed to dairy cows (Guyader et al., 2016a; Meller et al., 2019). Despite the absence of effects in our study, it is well established that $\mathrm{NO}_{3}{ }^{-}$has a slower conversion to $\mathrm{NH}_{3}-\mathrm{N}$ within the rumen compared with urea. In fact, $\mathrm{NO}_{3}{ }^{-}$reduction occurs in 2 steps, in which $\mathrm{NO}_{3}{ }^{-}$is first converted into $\mathrm{NO}_{2}{ }^{-}$, and posteriorly $\mathrm{NO}_{2}{ }^{-}$is converted into $\mathrm{NH}_{3}$ in a dissimilatory pathway (Leng, 2008; Lee et al., 2017b). In addition, $\mathrm{NO}_{3}{ }^{-}$could also be converted into $\mathrm{N}_{2} \mathrm{O}$ by denitrification, which is an additional step of the dissimilatory pathway (Latham et al., 2016; Torres et al., 2016).

The lack of effects observed on total VFA is in agreement with previous studies (Olijhoek et al., 2016; Meller et al., 2019). However, total VFA concentrations ( $\mathrm{m} M$ ) in our study were lower than reported earlier, probably due to the use of stomach tubes for collecting rumen fluid (Shen et al., 2012). Supplemental CAN increased the molar proportion of acetate and the acetate-topropionate ratio, and the results are in agreement with previous studies (Božic et al., 2009; Zhou et al., 2012; Latham et al., 2016). Similar responses in VFA proportions with $\mathrm{NO}_{3}{ }^{-}$supplementation were documented earlier (Patra and Yu, 2013; Guyader et al., 2016b; Wang et al., 2018). The greater acetate production observed may be attributable to the stimulation of thermodynamically favorable pathway for $[\mathrm{H}]$ disposal during $\mathrm{NO}_{3}{ }^{-}$to $\mathrm{NH}_{3}$ conversion (Ungerfeld and Kohn, 2006). Nitrate reduction leads to a sharp decline in NADH and increased concentrations of $\mathrm{NAD}^{+}$, which favors greater production of acetate (Nolan et al., 2010).

\section{CONCLUSIONS}

Supplementing CAN at $30 \mathrm{~g} / \mathrm{kg}$ of DM to dairy cows decreased DMI and lowered milk fat and milk protein concentration, as well as increased molar proportions of ruminal acetate; however, no effects were observed on microbial protein synthesis. Low levels of $\mathrm{NO}_{3}{ }^{-}$and $\mathrm{NO}_{2}{ }^{-}$residues in milk, along with low MetHb in blood, validate the importance of gradual adaptation of dietary $\mathrm{NO}_{3}{ }^{-}$in lactating dairy cows. The effects of CAN on milk FA and antioxidant capacity observed in this study may have induced faster milk lipid oxidation, as it lowered SFA proportion and increased CD concentration, respectively. Based on these results, dietary CAN supplemented at $30 \mathrm{~g} / \mathrm{kg}$ of DM should not be recommended as an optimal dose for lactating dairy cows. However, data must be interpreted carefully due to the short period of animal exposure to $\mathrm{NO}_{3}{ }^{-}$.

\section{ACKNOWLEDGMENTS}

The authors thank the Coordenação de Aperfeicoamento de Pessoal de Nível Superior (CAPES, Brasília, Brazil) for granting the scholarship to the first author (finance code 001), Conselho Nacional de Desenvolvimento Científico e Tecnológico (CNPq, Brasília, Bra- 
zil) for the financial support through project number 405.689/2016-0, GRASP (Curitiba, Brazil) for providing supplies used in the study, members of the study group Núcleo de pesquisa e estudo em pecuária leiteira (NUPEL, Maringá, Brazil; Jean Lourenço, Monique Figueredo, Thomer Durman, Josiane Elias, Regina Pinto, Beatriz Tuzzi, and Ranulfo Silva-Junior) for all their support during the experiment, and all dairy unit collaborators of the State University of Maringa (Maringa, Brazil). The authors have not stated any conflicts of interest.

\section{REFERENCES}

Alaboudi, A. R., and G. A. Jones. 1985. Effect of acclimation to high nitrate intakes on some rumen fermentation parameters in sheep. Can. J. Anim. Sci. 65:841-849. https://doi.org/10.4141/cjas85 -099 .

Almeida, K. V. 2021a. Supplemental Table S1. Effects of calcium ammonium nitrate fed to dairy cows on nutrient intake and digestibility, milk quality, microbial protein synthesis, and ruminal fermentation parameters. figshare. Dataset. https://doi.org/10.6084/ m9.figshare.17159195.v2.

Almeida, K. V. 2021b. Supplemental Table S2. Effects of calcium ammonium nitrate fed to dairy cows on nutrient intake and digestibility, milk quality, microbial protein synthesis, and ruminal fermentation parameters. figshare. Dataset. https://doi.org/10.6084/ m9.figshare.17159225.v2.

Almeida, K. V. 2021c. Supplemental Figure S1. Effects of calcium ammonium nitrate fed to dairy cows on nutrient intake and digestibility, milk quality, microbial protein synthesis, and ruminal fermentation parameters. figshare. Figure. https://doi.org/10.6084/ m9.figshare.17159240.v2.

Almeida, K. V. 2021d. Supplemental Figure S2. Effects of calcium ammonium nitrate fed to dairy cows on nutrient intake and digestibility, milk quality, microbial protein synthesis, and ruminal fermentation parameters. figshare. Figure. https://doi.org/10.6084/ m9.figshare.17159252.v2.

AOAC International. 2012. Official Methods of Analysis. 19th ed. AOAC International.

Beauchemin, K. A., E. M. Ungerfeld, R. J. Eckard, and M. Wang. 2020. Review: Fifty years of research on rumen methanogenesis: Lessons learned and future challenges for mitigation. Animal 14:s2-s16. https://doi.org/10.1017/S1751731119003100.

Box, G. E. P., and D. R. Cox. 1964. An analysis of transformations revisited. J. R. Stat. Soc. A 26:211-252.

Božic, A. K., R. C. Anderson, G. E. Carstens, S. C. Ricke, T. R. Callaway, M. T. Yokoyama, J. K. Wang, and D. J. Nisbet. 2009. Effects of the methane-inhibitors nitrate, nitroethane, lauric acid, Lauricidin ${ }^{\circledR}$ and the Hawaiian marine algae Chaetoceros on ruminal fermentation in vitro. Bioresour. Technol. 100:4017-4025. https:// doi.org/10.1016/j.biortech.2008.12.061.

Broderick, G. A., and J. H. Kang. 1980. Automated simultaneous determination of ammonia and total amino acids in ruminal fluid and in vitro media. J. Dairy Sci. 63:64-75. https://doi.org/10 .3168/jds.S0022-0302(80)82888-8.

Bruning-Fann, C. S., and J. B. Kaneene. 1993. The effects of nitrate, nitrite and N-nitroso compounds on human health: A review. Vet. Hum. Toxicol. 35:521-538.

Bryan, N. S., and H. van Grinsven. 2013. The Role of Nitrate in Human Health. Academic Press. https://doi.org/10.1016/B978-0-12 -407247-3.00003-2.

Chen, X. B., and M. J. Gomes. 1992. Estimation of microbial protein supply to sheep and cattle based on urinary excretion of purine derivatives - An overview of the technical details. Accessed Feb. 18, 2018. https://www.researchgate.net/publication/265323654.
Cochran, R. C., D. C. Adams, J. D. Wallace, and M. L. Galyean. 1986. Predicting digestibility of different diets with internal markers: Evaluation of four potential markers. J. Anim. Sci. 63:1476-1483. https://doi.org/10.2527/jas1986.6351476x.

Cortas, N. K., and N. W. Wakid. 1990. Determination of inorganic nitrate in serum and urine by a kinetic cadmium-reduction method. Clin. Chem. 36:1440-1443. https://doi.org/10.1093/clinchem/36.8 .1440 .

DeVries, T. J., and R. M. Gill. 2012. Adding liquid feed to a total mixed ration reduces feed sorting behavior and improves productivity of lactating dairy cows. J. Dairy Sci. 95:2648-2655. https:// doi.org/10.3168/jds.2011-4965.

Dewhurst, R. J., D. R. Davies, and R. J. Merry. 2000. Microbial protein supply from the rumen. Anim. Feed Sci. Technol. 85:1-21. https://doi.org/10.1016/S0377-8401(00)00139-5.

Feng, X. Y., J. Dijkstra, A. Bannink, S. van Gastelen, J. France, and E. Kebreab. 2020. Antimethanogenic effects of nitrate supplementation in cattle: A meta-analysis. J. Dairy Sci. 103:11375-11385. https://doi.org/10.3168/jds.2020-18541.

Guillén, M. D., and N. Cabo. 2002. Fourier transform infrared spectra data versus peroxide and anisidine values to determine oxidative stability of edible oils. Food Chem. 77:503-510. https://doi.org/10 .1016/S0308-8146(01)00371-5.

Guyader, J., M. Doreau, D. P. Morgavi, C. Gérard, C. Loncke, and C. Martin. 2016a. Long-term effect of linseed plus nitrate fed to dairy cows on enteric methane emission and nitrate and nitrite residuals in milk. Animal 10:1173-1181. https://doi.org/10.1017/ S1751731115002852.

Guyader, J., M. Tavendale, C. Martin, and S. Muetzel. 2016b. Doseresponse effect of nitrate on hydrogen distribution between rumen fermentation end products: An in vitro approach. Anim. Prod. Sci. 56:224-230. https://doi.org/10.1071/AN15526.

Hamilton, R. J. 1983. The chemistry of rancidity in foods. Pages 1-21 in Rancidity in Foods. J. C. Allen and R. J. Hamilton, ed. Applied Science Publishers.

Hristov, A. N., A. Bannink, L. A. Crompton, P. Huhtanen, M. Kreuzer, M. McGee, P. Nozière, C. K. Reynolds, A. R. Bayat, D. R. Yáñez-Ruiz, J. Dijkstra, E. Kebreab, A. Schwarm, K. J. Shingfield, and Z. Yu. 2019. Invited review: Nitrogen in ruminant nutrition: A review of measurement techniques. J. Dairy Sci. 102:5811-5852. https://doi.org/10.3168/jds.2018-15829.

ISO. 1978. Animal and vegetable fats and oils-Preparation of methyl esters of fatty acids. ISO 5509:2000. International Organization for Standardization.

Jadhav, S. J., S. S. Nimbalkar, A. D. Kulkarni, and D. L. Madhavi. 1996. Lipid oxidation in biological and food systems. Pages 5-64 in Food Antioxidants: Technological, Toxicological, and Health Perspectives. D. L. Madhavi, S. S. Deshpande, and D. K. Salunkhe, ed. Marcel Dekker Inc.

Jorgensen, E., and A.R. Pedersen. 1998. How to obtain those nasty standard errors from transformed data-And why they should not be used. Biometry Research Unit, Danish Institute of Agricultural Sciences Accessed Jun. 22, 2020. http://citeseerx.ist.psu.edu/ viewdoc/summary?doi=10.1.1.47.9023.

Khan, I. T., M. Nadeem, M. Imran, R. Ullah, M. Ajmal, and M. H. Jaspal. 2019. Antioxidant properties of Milk and dairy products: A comprehensive review of the current knowledge. Lipids Health Dis. 18:41. https://doi.org/10.1186/s12944-019-0969-8.

Kiokias, S. N., C. P. Dimakou, I. V. Tsaprouni, and V. Oreopoulou. 2006. Effect of compositional factors against the thermal oxidative deterioration of novel food emulsions. Food Biophys. 1:115-123. https://doi.org/10.1007/s11483-006-9015-2.

Klop, G., B. Hatew, A. Bannink, and J. Dijkstra. 2016. Feeding nitrate and docosahexaenoic acid affects enteric methane production and milk fatty acid composition in lactating dairy cows. J. Dairy Sci. 99:1161-1172. https://doi.org/10.3168/jds.2015-10214.

Latham, E. A., R. C. Anderson, W. E. Pinchak, and D. J. Nisbet. 2016. Insights on alterations to the rumen ecosystem by nitrate and nitrocompounds. Front. Microbiol. 7:228. https://doi.org/10 $.3389 /$ fmicb.2016.00228. 
Lee, C., R. C. Araujo, K. M. Koenig, and K. A. Beauchemin. 2015a. Effects of encapsulated nitrate on enteric methane production and nitrogen and energy utilization in beef heifers. J. Anim. Sci. 93:2391-2404. https://doi.org/10.2527/jas.2014-8845.

Lee, C., R. C. Araujo, K. M. Koenig, and K. A. Beauchemin. 2017a. Effects of encapsulated nitrate on growth performance, carcass characteristics, nitrate residues in tissues, and enteric methane emissions in beef steers: Finishing phase. J. Anim. Sci. 95:3712. https://doi.org/10.2527/jas.2017.1461.

Lee, C., R. C. Araujo, K. M. Koenig, and K. A. Beauchemin. 2017b. In situ and in vitro evaluations of a slow release form of nitrate for ruminants: Nitrate release rate, rumen nitrate metabolism and the production of methane, hydrogen, and nitrous oxide. Anim. Feed Sci. Technol. 231:97-106. https://doi.org/10.1016/j.anifeedsci 2017.07.005

Lee, C., R. C. Araujo, K. M. Koenig, and K. A. Beauchemin. 2015b. Effects of encapsulated nitrate on eating behavior, rumen fermentation, and blood profile of beef heifers fed restrictively or ad libitum. J. Anim. Sci. 93:2405-2418. https://doi.org/10.2527/jas.2014 -8851 .

Lee, C., and K. A. Beauchemin. 2014. A review of feeding supplementary nitrate to ruminant animals: Nitrate toxicity, methane emissions, and production performance. Can. J. Anim. Sci. 94:557-570. https://doi.org/10.4141/cjas-2014-069.

Leng, R. A. 2008. The potential of feeding nitrate to reduce enteric methane production in ruminants. A Report to the Department of Climate Change, Commonwealth Government of Australia, Canberra. Accessed Jul. 10, 2020. http://www.penambulbooks.com/ Downloads/Leng-Final\%20Modified\%20\%2017-9-2008.pdf.

Li, L., J. Davis, J. Nolan, and R. Hegarty. 2012. An initial investigation on rumen fermentation pattern and methane emission of sheep offered diets containing urea or nitrate as the nitrogen source. Anim. Prod. Sci. 52:653-658. https://doi.org/10.1071/AN11254.

Lock, A. L., and D. E. Bauman. 2004. Modifying milk fat composition of dairy cows to enhance fatty acids beneficial to human health. Lipids 39:1197-1206. https://doi.org/10.1007/s11745-004-1348-6.

Lourenço, M., E. Ramos-Morales, and R. J. Wallace. 2010. The role of microbes in rumen lipolysis and biohydrogenation and their manipulation. Animal 4:1008-1023. https://doi.org/10.1017/ S175173111000042X.

Lund, P., R. Dahl, H. J. Yang, A. L. F. Hellwing, B. B. Cao, and M. R. Weisbjerg. 2014. The acute effect of addition of nitrate on in vitro and in vivo methane emission in dairy cows. Anim. Prod. Sci. 54:1432-1435. https://doi.org/10.1071/AN14339.

Lundberg, J. O., E. Weitzberg, and M. T. Gladwin. 2008. The nitratenitrite-nitric oxide pathway in physiology and therapeutics. Nat. Rev. Drug Discov. 7:156-167. https://doi.org/10.1038/nrd2466.

Meller, R. A., B. A. Wenner, J. Ashworth, A. M. Gehman, J. Lakritz, and J. L. Firkins. 2019. Potential roles of nitrate and live yeast culture in suppressing methane emission and influencing ruminal fermentation, digestibility, and milk production in lactating Jersey cows. J. Dairy Sci. 102:6144-6156. https://doi.org/10.3168/ jds.2018-16008.

Murphy, J. J., J. F. Connolly, and G. P. McNeill. 1995. Effects on milk fat composition and cow performance of feeding concentrates containing full fat rapeseed and maize distillers grains on grass-silage based diets. Livest. Prod. Sci. 44:1-11. https://doi.org/10.1016/ 0301-6226(95)00049-Q.

Nolan, J. V., R. S. Hegarty, J. Hegarty, I. R. Godwin, and R. Woodgate. 2010. Effects of dietary nitrate on fermentation, methane production and digesta kinetics in sheep. Anim. Prod. Sci. 50:801806. https://doi.org/10.1071/AN09211.

NRC. 2001. Nutrient Requirements of Dairy Cattle. 7th ed. National Academies Press.

Olijhoek, D. W., A. L. F. Hellwing, M. Brask, M. R. Weisbjerg, O. Højberg, M. K. Larsen, J. Dijkstra, E. J. Erlandsen, and P. Lund. 2016. Effect of dietary nitrate level on enteric methane production, hydrogen emission, rumen fermentation, and nutrient digestibility in dairy cows. J. Dairy Sci. 99:6191-6205. https://doi.org/10 $.3168 /$ jds.2015-10691.
Patra, A. K., and Z. Yu. 2013. Effective reduction of enteric methane production by a combination of nitrate and saponin without adverse effect on feed degradability, fermentation, or bacterial and archaeal communities of the rumen. Bioresour. Technol. 148:352360. https://doi.org/10.1016/j.biortech.2013.08.140.

Popova, M., J. Guyader, M. Silberberg, A. R. Seradj, C. Saro, A. Bernard, C. Gérard, C. Martin, and D. P. Morgavi. 2019. Changes in the rumen microbiota of cows in response to dietary supplementation with nitrate, linseed, and saponin alone or in combination. Appl. Environ. Microbiol. 85. https://doi.org/10.1128/AEM.02657 -18 .

Rebelo, L. R., I. C. Luna, J. D. Messana, R. C. Araujo, T. A. Simioni, Y. T. Granja-Salcedo, E. S. Vito, C. Lee, I. A. M. A. Teixeira, J. A. Rooke, and T. T. Berchielli. 2019. Effect of replacing soybean meal with urea or encapsulated nitrate with or without elemental sulfur on nitrogen digestion and methane emissions in feedlot cattle. Anim. Feed Sci. Technol. 257:114293. https://doi.org/10 .1016/j.anifeedsci.2019.114293.

Sharifi, M., A. Taghizadeh, A. Hosseinkhani, H. Mohammadzadeh, V. Palangi, M. Macit, A. Z. M. Salem, and S. Abachi. 2021. Nitrate supplementation at two forage levels in dairy cows feeding: Milk production and composition, fatty acid profiles, blood metabolites, ruminal fermentation, and hydrogen sink. Ann. Anim. Sci. 2021:1-28. https://doi.org/10.2478/aoas-2021-0044.

Shen, J. S., Z. Chai, L. J. Song, J. X. Liu, and Y. M. Wu. 2012. Insertion depth of oral stomach tubes may affect the fermentation parameters of ruminal fluid collected in dairy cows1. J. Dairy Sci. 95:5978-5984. https://doi.org/10.3168/jds.2012-5499.

Silanikove, N., F. Shapiro, M. Silanikove, U. Merin, and G. Leitner. 2009. Hydrogen peroxide-dependent conversion of nitrite to nitrate as a crucial feature of bovine milk catalase. J. Agric. Food Chem. 57:8018-8025. https://doi.org/10.1021/jf900618w.

Silanikove, N., A. Rauch-Cohen, F. Shapiro, A. Arieli, U. Merin, and G. Leitner. 2012. Lipopolysaccharide challenge of the mammary gland in cows induces nitrosative stress that impairs milk oxidative stability. Animal 6:1451-1459. https://doi.org/10.1017/ S1751731112000201.

Sinclair, L. A., P. C. Garnsworth, J. R. Newbold, and P. J. Buttery. 1993. Effect of synchronizing the rate of dietary energy and nitrogen release on rumen fermentation and microbial protein synthesis in sheep. J. Agric. Sci. 120:251-263. https://doi.org/10.1017/ S002185960007430X.

Sjaunja, L. O., L. Bævre, L. Junkkarinen, J. Pedersen, and J. Setälä. 1990. A Nordic proposal for an energy corrected milk (ECM) formula. Pages 156-157 in 27th Session of the International Commission for Breeding and Productivity of Milk Animals. Wageningen Academic Publishers.

Sklan, D., R. Ashkenazi, A. Braun, A. Devorin, and K. Tabori. 1992. Fatty acids, calcium soaps of fatty acids, and cottonseeds fed to high yielding cows. J. Dairy Sci. 75:2463-2472. https://doi.org/10 .3168/jds.S0022-0302(92)78008-4.

Titov, V. Y., O. V. Kosenko, V. I. Fisinin, and N. T. Klimov. 2010. Content of nitric oxide metabolites in cow milk in health and mastitis. Russ. Agric. Sci. 36:288-290. https://doi.org/10.3103/ S1068367410040178.

Torres, M. J., J. Simon, G. Rowley, E. J. Bedmar, D. J. Richardson, A. J. Gates, and M. J. Delgado. 2016. Nitrous Oxide Metabolism in Nitrate-Reducing Bacteria: Physiology and Regulatory Mechanisms. 1st ed. Elsevier Ltd.

Ungerfeld, E. M., and R. A. Kohn. 2006. The role of thermodynamics in the control of ruminal fermentation. Pages 55-85 in Ruminant Physiology: Digestion, Metabolism and Impact of Nutrition on Gene Expression, Immunology and Stress. M. O. Sejrsen, K. Hvelplund, and T. Nielsen, ed. Wageningen Academic Publishers.

Valadares, R. F. D., G. A. Broderick, S. C. Valadares Filho, and M. K. Clayton. 1999. Effect of replacing alfalfa silage with high moisture corn on ruminal protein synthesis estimated from excretion of total purine derivatives. J. Dairy Sci. 82:2686-2696. https://doi.org/10 .3168/jds.S0022-0302(99)75525-6. 
Van Soest, P. J., J. B. Robertson, and B. A. Lewis. 1991. Methods for dietary fiber, neutral detergent fiber, and nonstarch polysaccharides in relation to animal nutrition. J. Dairy Sci. 74:3583-3597. https://doi.org/10.3168/jds.S0022-0302(91)78551-2.

van Wyngaard, J. D. V., R. Meeske, and L. J. Erasmus. 2018. Effect of dietary nitrate on enteric methane emissions, production performance and rumen fermentation of dairy cows grazing kikuyu-dominant pasture during summer. Anim. Feed Sci. Technol. 244:76-87. https://doi.org/10.1016/j.anifeedsci.2018.08.005.

van Zijderveld, S. M., W. J. J. Gerrits, J. Dijkstra, J. R. Newbold, R. B. A. Hulshof, and H. B. Perdok. 2011. Persistency of methane mitigation by dietary nitrate supplementation in dairy cows. J. Dairy Sci. 94:4028-4038. https://doi.org/10.3168/jds.2011-4236.

Vyncke, W. 1970. Direct determination of the thiobarbituric acid value in trichoracetic acid extracts of fish as a measure of oxidative rancidity. Fette Seifen Anstrichm. 72:1084-1087.

Wang, R., M. Wang, E. M. Ungerfeld, X. M. Zhang, D. L. Long, H. X. Mao, J. P. Deng, A. Bannink, and Z. L. Tan. 2018. Nitrate improves ammonia incorporation into rumen microbial protein in lactating dairy cows fed a low-protein diet. J. Dairy Sci. 101:97899799. https://doi.org/10.3168/jds.2018-14904.
WHO. 2011. Chemical Fact Sheets. 4th ed. World Health Organization.

Yang, C., N. McKain, C. A. McCartney, and R. J. Wallace. 2019. Consequences of inhibiting methanogenesis on the biohydrogenation of fatty acids in bovine ruminal digesta. Anim. Feed Sci. Technol. 254:114189. https://doi.org/10.1016/j.anifeedsci.2019.05.012.

Zhao, X., J. Wang, Y. Yang, D. Bu, H. Cui, Y. Sun, X. Xu, and L. Zhou. 2013. Effects of different fat mixtures on milk fatty acid composition and oxidative stability of milk fat. Anim. Feed Sci. Technol. 185:35-42. https://doi.org/10.1016/j.anifeedsci.2013.06 .009 .

Zhou, Z., Z. Yu, and Q. Meng. 2012. Effects of nitrate on methane production, fermentation, and microbial populations in in vitro ruminal cultures. Bioresour. Technol. 103:173-179. https://doi.org/ 10.1016/j.biortech.2011.10.013.

Zhu, Q. Y., R. M. Hackman, J. L. Ensunsa, R. R. Holt, and C. L. Keen. 2002. Antioxidative activities of oolong tea. J. Agric. Food Chem. 50:6929-6934. https://doi.org/10.1021/jf0206163. 